\title{
Anti-tumor necrosis factor- $\alpha$ for the treatment of steroid-refractory acute graft-versus-host disease
}

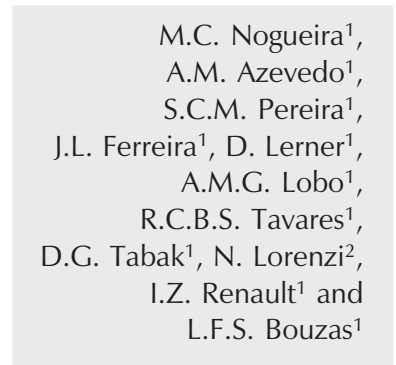

${ }^{1}$ Centro de Transplante de Medula Óssea, ${ }^{2}$ Serviço de Farmácia, Instituto Nacional de Câncer, Rio de Janeiro, RJ, Brasil

\section{Correspondence}

M.C. Nogueira

Centro de Transplante de

Medula Óssea

Instituto Nacional de Câncer

Praça Cruz Vermelha 23, 7o andar

20230-130 Rio de Janeiro, RJ

Brasil

Fax: +55-21-2509-2121

E-mail: colares.marta@gmail.com

....................

Received October 5, 2006

Accepted May 9, 2007

\section{Abstract}

Allogeneic stem cell transplantation has been increasingly performed for a variety of hematologic diseases. Clinically significant acute graft-versus-host disease (GVHD) occurs in 9 to $50 \%$ of patients who receive allogeneic grafts, resulting in high morbidity and mortality. There is no standard therapy for patients with acute GVHD who do not respond to steroids. Studies have shown a possible benefit of antiTNF- $\alpha$ (infliximab) for the treatment of acute GVHD. We report here on the outcomes of 10 recipients of related or unrelated stem cell transplants who received $10 \mathrm{mg} / \mathrm{kg}$ infliximab, $i v$, once weekly for a median of 3.5 doses (range: 1-6) for the treatment of severe acute GVHD and who were not responsive to standard therapy. All patients had acute GVHD grades II to IV ( $\mathrm{II}=2, \mathrm{III}=3, \mathrm{IV}=5$ ). Overall, 9 patients responded and 1 patient had progressive disease. Among the responders, 3 had complete responses and 6 partial responses. All patients with cutaneous or gastrointestinal involvement responded, while only 2 of 6 patients with liver disease showed any response. None of the 10 patients had any kind of immediate toxicity. Four patients died, all of them with sepsis. Six patients are still alive after a median follow-up time of 544 days (92-600) after transplantation. Considering the severity of the cases and the bad prognosis associated with advanced acute GVHD, we find our results encouraging. AntiTNF- $\alpha$ seems to be a useful agent for the treatment of acute GVHD.

\section{Introduction}

Transplantation with allogeneic bone marrow or peripheral blood has been increasingly performed for a variety of hematologic diseases. Clinically significant acute
Key words

- Infliximab

- Graft-versus-host disease

- Hematopoietic stem cell transplantation 
munosuppressive regimen, typically with high-dose steroids. However, there is no standard therapy for patients with acute GVHD who fail to respond to an initial course of corticosteroids (1).

Tumor necrosis factor alpha (TNF- $\alpha)$ is an important cytokine involved in the pathophysiology of acute GVHD (2-5). Infliximab is a chimeric human anti-TNF- $\alpha$ IgG1 monoclonal antibody (6). Studies have shown a possible benefit of anti-TNF- $\alpha$ antibody as treatment for acute GVHD (7-10).

We report here on the outcomes of 10 patients treated with infliximab against severe acute GVHD at our institution.

\section{Patients and Methods}

\section{Patients}

Between July 2003 and January 2006, 10 patients with a median age of 13 years (range: 4-36 years) with steroid-refractory acute GVHD received infliximab at our institution. These patients were retrospectively analyzed. The characteristics of the patients and transplants are shown in Table 1.

\section{Transplants}

GVHD prophylaxis was done with cyclosporine and prednisone in all patients who received cord blood, and with cyclosporine and methotrexate in those who received either bone marrow or peripheral blood stem cells. The characteristics of the transplants are shown in Table 1.

\section{Graft-versus-host disease}

Acute GVHD was diagnosed within 100 days of allogeneic transplantation or donor lymphocyte infusion. Acute GVHD was staged and graded according to modified Glucksberg criteria (11). GVHD that developed 100 days after allogeneic transplantation was considered to be chronic GVHD. At the start of infliximab treatment, 2 patients had developed grade II acute GVHD, while 8 had developed either grade III or IV acute GVHD. The liver was compromised in 6 (grades 1-4; median $=2$ ), the gastrointestinal tract (GIT) in 8 (grades $1-4$; median = 3.5 ), and the skin in all (grades 1-4; median $=3$ ). Sicca syndrome was present in one

Table 1. Characteristics of patients and transplants.

\begin{tabular}{rrrlcccccc}
\hline No. & Sex & $\begin{array}{c}\text { Age } \\
\text { (years) }\end{array}$ & Diagnosis & $\begin{array}{c}\text { Type of } \\
\text { donor }\end{array}$ & $\begin{array}{c}\text { HLA- } \\
\text { identical }\end{array}$ & $\begin{array}{c}\text { Loci of } \\
\text { mismatch }\end{array}$ & $\begin{array}{c}\text { Cell } \\
\text { source }\end{array}$ & Conditioning & $\begin{array}{c}\text { GVHD } \\
\text { prophylaxis }\end{array}$ \\
\hline 1 & $\mathrm{~F}$ & 36 & AML & $\mathrm{R}$ & Yes & & BM & Bu/Flu & CSP/MTX \\
2 & M & 21 & CML-BC & U & Yes & & PB & ATG/Cy/TBI & CSP/MTX \\
3 & M & 13 & ALL & R & Yes & & BM & Cy/TBI & CSP/MTX \\
4 & M & 6 & Krabbe disease & U & No & DR & CB & Flu/TBI & CSP/Pred \\
5 & M & 4 & ALL & U & No & B, DR & CB & ATG/Cy/TBI & CSP/Pred \\
6 & M & 21 & CML-CP & U & Yes & & BM & ATG/Cy/TBI & CSP/MTX \\
7 & M & 6 & ALL & U & Yes & & BM & ATG/Cy/TBI & CSP/MTX \\
8 & F & 13 & AML & U & No & B & PB & ATG/Cy/TBI & CSP/MTX \\
9 & M & 8 & ALL & U & No & A, B & CB & ATG/Cy/TBI & CSP/Pred \\
10 & F & 35 & CML-CP & R & Yes & & BM & Bu/Cy & CSP/MTX \\
\hline
\end{tabular}

GVHD = graft-versus-host disease; $\mathrm{F}=$ female; $\mathrm{M}=$ male; $\mathrm{AML}=$ acute myelocytic leukemia; $\mathrm{CML}-\mathrm{BC}=$ chronic myelogenous leukemia-blast crisis; $\mathrm{ALL}=$ acute lymphocytic leukemia; $\mathrm{CML}-\mathrm{CP}=$ chronic myelogenous leukemia-chronic phase; $\mathrm{R}=$ related; $\mathrm{U}=$ unrelated; $\mathrm{BM}=$ bone marrow; $\mathrm{PB}=$ peripheral blood; $\mathrm{CB}=$ cord blood; $\mathrm{Bu}=$ busulphan; Flu = fludarabine; $\mathrm{ATG}=$ anti-thymocyte globulin; $\mathrm{Cy}=$ cyclophosphamide; $\mathrm{TBI}=$ total-body irradiation; CSP = cyclosporine; MTX = methotrexate; Pred = methylprednisolone. 
patient, and isolated xerophthalmia in another. The data about GVHD are shown in Table 2.

\section{Treatment of graft-versus-host disease}

Before starting infliximab, all 10 patients were receiving a combination of methylprednisolone, $2 \mathrm{mg} \mathrm{kg}^{-1}$ day $^{-1}$, $i v$, with a calcineurin inhibitor (9 on cyclosporine, 1 on tacrolimus). Patients 1,3 , and 10 were also on mycophenolate mofetil, which is the drug of choice in our service, once steroid refractory acute GVHD occurs. Patient number 3 also received basiliximab and was started on extracorporeal photopheresis for severe cutaneous involvement. Patients 5, 6, 7, 8, and 9 were switched from cyclosporine to tacrolimus in view of the reports of better results in unrelated bone marrow transplants with the latter drug. Since patient number 6 had developed hemolyticuremic syndrome attributed to tacrolimus and was not able to start mycophenolate mofetil because of pancytopenia, he was started on thalidomide. All 10 patients received inflixi$\mathrm{mab}, 10 \mathrm{mg} / \mathrm{kg}, i v$, once weekly for a median of 3.5 doses (range: 1-6).

After the start of infliximab, all patients continued to receive methylprednisolone, 2 $\mathrm{mg} \mathrm{kg}^{-1} \mathrm{day}^{-1}$, iv, in divided doses. Cortico- steroids were progressively tapered and discontinued as GVHD improved. The median time between the introduction of corticosteroids and the start of infliximab was 20.5 days (10-33) (Table 2). Details are shown in Table 3.

\section{Response}

The overall response represented the responses of the skin, GIT and liver. Complete response was defined as resolution of GVHD in all evaluable organs, partial response as any improvement in at least one evaluable organ without deterioration of others, and no response as the absence of any change or any situation other than complete or partial response, or progressive disease (7).

\section{Results}

\section{Evaluation of the response}

Overall, 9 patients responded and one patient had progressive disease. Among the responders, 3 had a complete response and 6 had a partial response. Only 2 of 6 patients with liver disease showed any grade of liver improvement, while all patients with either cutaneous or GIT involvement had responses

Table 2. Graft-versus-host disease (GVHD) characteristics and response to infliximab.

\begin{tabular}{|c|c|c|c|c|c|c|c|c|c|c|c|c|c|}
\hline \multirow[t]{2}{*}{ No. } & \multicolumn{4}{|c|}{ Grading of GVHD } & \multirow{2}{*}{$\begin{array}{l}\text { No. of doses of } \\
\text { infliximab }\end{array}$} & \multirow{2}{*}{$\begin{array}{l}\text { Days of corticosteroid before } \\
\text { infliximab was started }\end{array}$} & \multicolumn{4}{|c|}{ Response to infliximab } & \multirow{2}{*}{$\begin{array}{l}\text { Chronic } \\
\text { GVHD }\end{array}$} & \multicolumn{2}{|c|}{ Death } \\
\hline & Overall & Liver & GIT & Skin & & & Overall & Liver & GIT & Skin & & $\mathrm{Y} / \mathrm{N}$ & Cause \\
\hline 1 & IV & 2 & 4 & 1 & 3 & 28 & PD & No & No & No & Yes & Yes & Sepsis \\
\hline 2 & IV & 0 & 2 & 4 & 1 & 13 & $\mathrm{CR}$ & NA & Yes & Yes & Yes & No & NA \\
\hline 3 & II & 0 & 1 & 3 & 1 & 33 & PR & NA & Yes & Yes & Yes & No & NA \\
\hline 4 & IV & 4 & 4 & 3 & 4 & 20 & $\mathrm{CR}$ & Yes & Yes & Yes & Yes & No & NA \\
\hline 5 & II & 0 & 0 & 3 & 2 & 16 & $\mathrm{CR}$ & NA & NA & Yes & Yes & No & NA \\
\hline 6 & III & 2 & 0 & 3 & 4 & 32 & PR & No & NA & Yes & Yes & No & NA \\
\hline 7 & III & 1 & 1 & 3 & 6 & 10 & PR & No & Yes & Yes & Yes & Yes & Sepsis \\
\hline 8 & III & 0 & 3 & 3 & 3 & 16 & PR & NA & Yes & Yes & $\mathrm{NE}$ & Yes & Sepsis \\
\hline 9 & IV & 2 & 4 & 3 & 4 & 29 & PR & No & Yes & Yes & $\mathrm{NE}$ & Yes & Sepsis \\
\hline 10 & IV & 2 & 4 & 2 & 4 & 21 & PR & Yes & Yes & Yes & $\mathrm{NE}$ & No & NA \\
\hline
\end{tabular}

GIT = gastrointestinal tract; $\mathrm{PD}=$ progressive disease; $\mathrm{CR}=$ complete response; $\mathrm{PR}=$ partial response; $\mathrm{NA}=$ not applicable; $\mathrm{NE}=$ not evaluated . 
in these organs. Seven patients had progressive chronic GVHD, 3 were not evaluable (2 died before day 100, and 1 was on day 92 by the time of the analysis). The data are summarized in Table 2.

\section{Toxicity and infections}

None of the 10 patients had any kind of infusion-related, immediate toxicity. Nevertheless, all of them had a diagnosis of infection. Four had febrile neutropenia, 4 had cutaneous infections, 3 had a clinical diagnosis of sinusitis confirmed by computed tomographic scan, 3 had pneumonia, 1 had hemorrhagic cystitis, 1 had encephalitis, and 1 had oral candidiasis. Seven bacterial infections were microbiologically documented in four patients: Pseudomonas $\mathrm{sp}(\mathrm{N}=1)$, Streptococcus $\mathrm{sp}(\mathrm{N}=2)$, Staphylococcus $\mathrm{sp}(\mathrm{N}=$ $2)$, and Enterococcus sp $(\mathrm{N}=2)$. One patient had pneumonia, with Pneumocystis carinii identified in the sputum. Eight patients developed cytomegalovirus infection detected by antigenemia, but none progressed to cytomegalovirus disease. Fungal infections occurred in 3 patients: 1 patient had a subcutaneous abscess due to Aspergillus sp, which resolved after surgical drainage and specific antifungal therapy. The other 2 patients died of sepsis due to Fusarium sp; 1 had only cutaneous lesions and the other had cutaneous as well as cerebral involvement. Data about infectious complications are summarized in Tables 4 and 5.

\section{Outcomes}

Four patients died. Two of them, who had controlled GVHD, died of fungal infections. One patient whose GVHD had also been controlled died with bacterial sepsis. The last one had progressive GVHD and also died due to bacterial sepsis. Six patients are still alive, with chronic GVHD, at a median of 544 days (92-600) after the transplant. All 6 had either a partial or complete response to infliximab.

Table 3. Immunosuppressive treatments.

\begin{tabular}{|c|c|c|c|c|c|c|c|c|c|c|}
\hline \multirow[t]{2}{*}{ No. } & \multicolumn{5}{|c|}{ Immunosuppression before the introduction of infliximab } & \multicolumn{5}{|c|}{ Immunosuppression after the introduction of infliximab } \\
\hline & $\begin{array}{l}\text { CSP serum } \\
\text { level }(\mathrm{ng} / \mathrm{mL})\end{array}$ & $\begin{array}{c}\text { Pred } \\
\left(\mathrm{mg} \mathrm{kg}^{-1} \text { day }^{-1}\right)\end{array}$ & $\begin{array}{l}\text { MMF } \\
\text { (g/day) }\end{array}$ & $\begin{array}{c}\text { FK506 } \\
\left(\mathrm{mg} \mathrm{kg}^{-1} \text { day-1}^{-1}\right)\end{array}$ & Other & $\begin{array}{l}\text { CSP serum } \\
\text { level }(\mathrm{ng} / \mathrm{mL})\end{array}$ & $\begin{array}{c}\text { Pred } \\
\left(\mathrm{mg} \mathrm{kg}^{-1} \text { day }^{-1}\right)\end{array}$ & $\begin{array}{l}\text { MMF } \\
\text { (g/day) }\end{array}$ & $\begin{array}{c}\text { FK506 } \\
\left(\mathrm{mg} \mathrm{kg}^{-1} \mathrm{day}^{-1}\right)\end{array}$ & Other \\
\hline 1 & No & 2 & 1.5 & 0.03 & No & No & 2 & No & 0.03 & No \\
\hline 2 & 478 & 2 & No & No & No & 589 & 2 & No & No & No \\
\hline 3 & 289 & 2 & 1.5 & No & Basiliximab & 339 & 2 & 1.5 & No & ECP \\
\hline 4 & 332 & 2 & No & No & No & 432 & 2 & No & No & No \\
\hline 5 & 405 & 2 & No & No & No & 80 & 2 & No & 0.03 & No \\
\hline 6 & 229 & 2 & No & No & No & 274 & 2 & No & 0.03 & Thal \\
\hline 7 & 297 & 2 & No & No & No & 429 & 2 & No & 0.03 & No \\
\hline 8 & 308 & 2 & No & No & No & NA & 2 & No & 0.03 & No \\
\hline 9 & 228 & 2 & No & No & No & 278 & 2 & No & 0.03 & No \\
\hline 10 & 459 & 2 & 2 & No & No & 93 & 2 & 2 & No & No \\
\hline
\end{tabular}

CSP = cyclosporine; Pred = methylprednisolone; MMF = mycophenolate mofetil; FK506 = tacrolimus; ECP = extracorporeal photopheresis; Thal $=$ thalidomide; NA = not available. Serum levels of CSP were measured twice weekly. The values shown reflect the nearest measurements to the day of infliximab start. Patient 1 was unresponsive to CSP/Pred and was switched to FK506. Patient 3 had severe cutaneous involvement and received basiliximab and ECP in view of the good results already reported in the literature. Patient 5 developed microangiopathic hemolysis that was attributed to CSP toxicity and was switched to FK506. Patient 6 developed microangiopathic hemolysis that was attributed to CSP toxicity and was first switched to FK506 without improvement of hemolysis; thalidomide was then substituted. Patients 7, 8 and 9 were unresponsive to CSP/ Pred and were switched to FK506 in view of the good results reported for GVHD in unrelated transplants with this drug. Patient 10 developed microangiopathic hemolysis and acute renal failure that were attributed to CSP toxicity and was switched to MMF. 


\section{Discussion}

Despite the use of prophylactic immunosuppressive regimens, grades II-IV acute GVHD occur in 30 to $80 \%$ of allogeneic transplant recipients, with greater frequency after transplantation from HLA non-identical or unrelated donors (12-14).

The pathophysiology of acute GVHD is triphasic $(15,16)$. The initial phase results from the damage induced by the conditioning regimen in host tissues. Damaged tissues secrete inflammatory cytokines, including interleukin-1, TNF- $\alpha$, and interferon-gamma. In the second phase, recipient antigenpresenting cells trigger the activation of donor-derived $\mathrm{T}$ cells, which expand and differentiate into effector cells $(17,18)$. In the third phase, the effector phase, activated donor $\mathrm{T}$ cells mediate cytotoxicity against target host cells through Fas-Fas ligand interactions, perforin-granzyme $\mathrm{B}$ and cytokine production, including production of TNF- $\alpha$ $(19,20)$. This sequence of events leads to the tissue damage that is characteristic of acute GVHD.

The standard of primary therapy for acute GVHD is considered to be methylprednisolone for 14 days, followed by a steroid taper (21). However, reports from the 1990's indicated that $80 \%$ of responses to corticosteroids, incomplete or complete, were not sustained. Failure was associated with a $75 \%$ non-relapse mortality rate $(22,23)$. When steroid therapy fails to control the manifestations of acute GVHD, there is no standard approach to secondary GVHD therapy.

TNF- $\alpha$ is a key cytotoxic and proinflammatory cytokine involved in the pathogenesis of GVHD. TNF- $\alpha$ induces apoptosis, activates macrophages, granulocytes and lymphocytes, and produces a cascade of other inflammatory cytokines. TNF- $\alpha$ also increases the expression of HLA molecules and facilitates cytolysis mediated by $\mathrm{T}$ lymphocytes (24). High levels of TNF- $\alpha$ have been correlated with the occurrence of acute and chronic GVHD $(3,24)$.

Infliximab is a chimeric monoclonal IgG1 antibody that inhibits TNF- $\alpha$ activity and triggers complement-mediated lysis of TNF$\alpha$-expressing cells in vitro (25-29). The drug binds to the soluble and transmembrane forms of TNF- $\alpha(6,28)$. Intravenous infusions of infliximab are FDA-approved for the management of Crohn's disease and rheumatoid arthritis.

In our series, 9 of 10 patients responded to infliximab, 3 with complete and 6 with partial responses. When considering organ involvement, 9 of 10 patients with cutaneous involvement responded, 7 of 8 with intestinal GVHD, and only 2 of 6 with liver disease. Couriel et al. (7) reported a 67\% overall response rate. These were primarily complete responses, and the highest response rates were observed in the GIT and skin. In the study of Patriarca et al. (9) there was a $59 \%$ response rate to infliximab, with $19 \%$ complete and $40 \%$ partial responses. Ac-

\begin{tabular}{lc} 
Table 4. Microbiologically documented infections. \\
\hline Infectious agent & No. of isolates \\
\hline Bacterial & 6 \\
$\quad$ Gram-positive & 1 \\
Gram-negative & \\
Fungal & 2 \\
Fusarium sp & 1 \\
$\quad$ Aspergillus sp & \\
Viral & 8 \\
$\quad$ Cytomegalovirus & 1 \\
$\quad$ Pneumocystis carinii & 19 \\
Total & \\
\hline
\end{tabular}

Table 5. Sites of infection.

\begin{tabular}{lc}
\hline Infection & No. of cases \\
\hline Sinusitis & 3 \\
Pneumonia & 3 \\
Cutaneous & 4 \\
Encephalitis & 1 \\
Cystitis & 1 \\
Total & 12 \\
\hline
\end{tabular}


cordingly, the best responses were also observed in the GIT. In the case series of Kobbe et al. (10), 3 of 4 patients responded to infliximab.

None of our patients had any kind of toxicity attributable to infliximab. Some studies have described adverse events, which include acute infusional toxicity, serum sickness, development of autoantibodies (21), and neurological (30) or hepatic complications (31), but most of the series do not report adverse events $(7,9,10)$.

Fungal infections, which were severe, occurred in 3 of our patients. TNF- $\alpha$ is essential for immune defense, playing a major role in the recruitment of inflammatory cells to the site of infection and in the formation and maintenance of granulomas (32). Marty et al. (1) reported on 5 cases of fungal infection in 11 patients who had received infliximab for the treatment of acute GVHD. In other studies, the incidence of fungal infections ranged from approximately $6 \%(2$ of 32 patients) (9) to $28 \%$ (6 of 21 patients) (7). The possibility that infliximab contributed to a higher risk of lethal infections cannot be ruled out; however, acute GVHD and its immunosuppressive treatment already put these patients at higher risk for these complications. Tuberculosis has also been described after the use of infliximab (32), but none of our patients developed this complication.

Our study has important limitations. First, the number of patients is small and the distribution of strong risk factors for GVHD such as the use of unrelated donors is not homogeneous. There was no consensus on the choice of different immunosuppressive agents once resistance to corticosteroids was recognized. Second, the rationale for the introduction of infliximab was not the same in every patient. Third, it is only a retrospective, uncontrolled study. Although the response to infliximab appeared to be significant, one cannot exclude the possibility of a late response to corticosteroids or any of the other immunosuppressive treatments simultaneously employed. Nevertheless, in view of the high morbidity and mortality of steroidresistant GVHD, we believe that these results may help justify the design of controlled, randomized clinical trials to investigate the subject further.

In summary, infliximab was well tolerated and appears to have a role in the treatment of acute GVHD, especially when the gastrointestinal tract is compromised. Randomized studies on the use of infliximab for the treatment of acute GVHD are underway (7) and the results are eagerly awaited.

\section{References}

1. Marty FM, Lee SJ, Fahey MM, Alyea EP, Soiffer RJ, Antin JH, et al. Infliximab use in patients with severe graft-versus-host disease and other emerging risk factors of non-Candida invasive fungal infections in allogeneic hematopoietic stem cell transplant recipients: a cohort study. Blood 2003; 102: 2768-2776.

2. Cohen J. Cytokines as mediators of graft-versus-host disease. Bone Marrow Transplant 1988; 3: 193-197.

3. Holler E, Kolb HJ, Moller A, Kempeni J, Liesenfeld S, Pechumer H, et al. Increased serum levels of tumor necrosis factor alpha precede major complications of bone marrow transplantation. Blood 1990; 75: 1011-1016.

4. Symington FW, Pepe MS, Chen AB, Deliganis A. Serum tumor necrosis factor alpha associated with acute graft-versus-host disease in humans. Transplantation 1990; 50: 518-521.

5. Shalaby MR, Fendly B, Sheehan KC, Schreiber RD, Ammann AJ.
Prevention of the graft-versus-host reaction in newborn mice by antibodies to tumor necrosis factor-alpha. Transplantation 1989; 47: 1057-1061.

6. Scallon BJ, Moore MA, Trinh H, Knight DM, Ghrayeb J. Chimeric anti-TNF-alpha monoclonal antibody $\mathrm{CA} 2$ binds recombinant transmembrane TNF-alpha and activates immune effector functions. $\mathrm{Cy}$ tokine 1995; 7: 251-259.

7. Couriel D, Saliba R, Hicks K, Ippoliti C, De Lima M, Hosing C, et al. Tumor necrosis factor-alpha blockade for the treatment of acute GVHD. Blood 2004; 104: 649-654.

8. Couriel DR, Hicks K, Giralt S, Champlin RE. Role of tumor necrosis factor-alpha inhibition with inflixiMAB in cancer therapy and hematopoietic stem cell transplantation. Curr Opin Oncol 2000; 12: 582587.

9. Patriarca F, Sperotto A, Damiani D, Morreale G, Bonifazi F, Olivieri 
A, et al. Infliximab treatment for steroid-refractory acute graft-versus-host disease. Haematologica 2004; 89: 1352-1359.

10. Kobbe G, Schneider P, Rohr U, Fenk R, Neumann F, Aivado M, et al. Treatment of severe steroid refractory acute graft-versus-host disease with infliximab, a chimeric human/mouse antiTNFalpha antibody. Bone Marrow Transplant 2001; 28: 47-49.

11. Przepiorka D, Weisdorf D, Martin P, Klingemann HG, Beatty $P$, Hows J, et al. 1994 Consensus Conference on Acute GVHD Grading. Bone Marrow Transplant 1995; 15: 825-828.

12. Storb R, Deeg HJ, Whitehead J, Appelbaum F, Beatty P, Bensinger $\mathrm{W}$, et al. Methotrexate and cyclosporine compared with cyclosporine alone for prophylaxis of acute graft versus host disease after marrow transplantation for leukemia. N Engl J Med 1986; 314: 729-735.

13. Beatty PG, Clift RA, Mickelson EM, Nisperos BB, Flournoy N, Martin $\mathrm{PJ}$, et al. Marrow transplantation from related donors other than HLA-identical siblings. N Engl J Med 1985; 313: 765-771.

14. Beatty PG, Hansen JA, Longton GM, Thomas ED, Sanders JE, Martin PJ, et al. Marrow transplantation from HLA-matched unrelated donors for treatment of hematologic malignancies. Transplantation 1991; 51: 443-447.

15. Chao NJ. Graft-versus-host disease: the viewpoint from the donor $T$ cell. Biol Blood Marrow Transplant 1997; 3: 1-10.

16. Ferrara JL, Levy R, Chao NJ. Pathophysiologic mechanisms of acute graft-vs.-host disease. Biol Blood Marrow Transplant 1999; 5: 347-356.

17. Blazar BR, Taylor PA, Panoskaltsis-Mortari A, Gray GS, Vallera DA. Coblockade of the LFA1:ICAM and CD28/CTLA4:B7 pathways is a highly effective means of preventing acute lethal graft-versus-host disease induced by fully major histocompatibility complex-disparate donor grafts. Blood 1995; 85: 2607-2618.

18. Rus V, Svetic A, Nguyen P, Gause WC, Via CS. Kinetics of Th1 and Th2 cytokine production during the early course of acute and chronic murine graft-versus-host disease. Regulatory role of donor CD8+ T cells. J Immunol 1995; 155: 2396-2406.

19. Goker H, Haznedaroglu IC, Chao NJ. Acute graft-vs-host disease: pathobiology and management. Exp Hematol 2001; 29: 259-277.
20. Graubert TA, Russell JH, Ley TJ. The role of granzyme B in murine models of acute graft-versus-host disease and graft rejection. Blood 1996; 87: 1232-1237.

21. Carpenter PA, Sanders JE. Steroid-refractory graft-vs.-host disease: past, present and future. Pediatr Transplant 2003; 7 (Suppl 3): 19-31.

22. Weisdorf D, Haake R, Blazar B, Miller W, McGlave P, Ramsay N, et al. Treatment of moderate/severe acute graft-versus-host disease after allogeneic bone marrow transplantation: an analysis of clinical risk features and outcome. Blood 1990; 75: 1024-1030.

23. Martin PJ, Schoch G, Fisher L, Byers V, Anasetti C, Appelbaum FR, et al. A retrospective analysis of therapy for acute graft-versus-host disease: initial treatment. Blood 1990; 76: 1464-1472.

24. Remberger M, Ringden $O$, Markling L. TNF alpha levels are increased during bone marrow transplantation conditioning in patients who develop acute GVHD. Bone Marrow Transplant 1995; 15: 99 104.

25. Gottlieb AB. Psoriasis. Immunopathology and immunomodulation Dermatol Clin 2001; 19: 649-57, viii.

26. Gottlieb AB, Bos JD. Recombinantly engineered human proteins: transforming the treatment of psoriasis. Clin Immunol 2002; 105: 105-116.

27. LaDuca JR, Gaspari AA. Targeting tumor necrosis factor alpha. New drugs used to modulate inflammatory diseases. Dermatol Clin 2001; 19: 617-635.

28. Lebwohl M. Psoriasis. Lancet 2003; 361: 1197-1204.

29. Williams JD, Griffiths CE. Cytokine blocking agents in dermatology. Clin Exp Dermatol 2002; 27: 585-590.

30. Jarand J, Zochodne DW, Martin LO, Voll C. Neurological complications of infliximab. J Rheumatol 2006; 33: 1018-1020.

31. Tobon GJ, Canas C, Jaller JJ, Restrepo JC, Anaya JM. Serious liver disease induced by infliximab. Clin Rheumatol 2007; 26: 578-581.

32. Gaemperli A, Hauser T, Speck R. Risk of infection during treatment with tumor necrosis factor-alpha inhibitors. Z Rheumatol 2006; 65: 24-28, 30-31. 